\title{
Therapy for metastatic melanoma: the past, present, and future
}

\author{
Laura Finn ${ }^{1}$, Svetomir N Markovic ${ }^{2}$ and Richard W Joseph ${ }^{1 *}$
}

\begin{abstract}
Metastatic melanoma is the most aggressive form of skin cancer with a median overall survival of less than one year. Advancements in our understanding of how melanoma evades the immune system as well as the recognition that melanoma is a molecularly

heterogeneous disease have led to major

improvements in the treatment of patients with metastatic melanoma. In 2011, the US Food and Drug Administration (FDA) approved two novel therapies for advanced melanoma: a BRAF inhibitor, vemurafenib, and an immune stimulatory agent, ipilimumab. The success of these agents has injected excitement and hope into patients and clinicians and, while these therapies have their limitations, they will likely provide excellent building blocks for the next generation of therapies. In this review we will discuss the advantages and limitations of the two new approved agents, current clinical trials designed to overcome these limitations, and future clinical trials that we feel hold the most promise.

Keywords: Melanoma, Vemurafenib, Ipilimumab, BRAF, Therapy
\end{abstract}

\section{Introduction}

With approximately 13,000 annual deaths and a median overall survival (OS) of 8 to 18 months, metastatic melanoma is the most aggressive form of skin cancer [1]. Until 2011, only two FDA therapies for metastatic melanoma were approved, dacarbazine and high dose interleukin 2 (HD IL-2), both of which do not increase median OS [2-4]. Dacarbazine is limited by a low response rate (10\% to $15 \%)$ and an overall survival of eight months [2]. HD IL-2 is limited by an even lower

\footnotetext{
* Correspondence: joseph.richard@mayo.edu

'Division of Hematology and Oncology, Mayo Clinic Florida, 4500 San Pablo Road, Jacksonville, FL 32224, USA

Full list of author information is available at the end of the article
}

response rate (6\% to $10 \%)$ and severe toxicity with only a minority of patients achieving a long-term, durable response $[3,4]$.

Recognition of key molecular mutations that drive tumorigenesis in melanoma has led to the development of promising agents that selectively target and inhibit these mutations and, in turn, provide improved response rates with decreased toxicity. Secondarily, advancements in our understanding of tumor immunology and immune escape have led to the emergence of newer immunologic agents that are less toxic than HD IL-2 but still provide long-term benefits. While these breakthroughs are encouraging, several limitations remain. In the case of vemurafenib, the duration of response is relatively short. In the case with ipilimumab, the response rate is low. The purpose of this review is to summarize the recent advances in the treatment of metastatic melanoma, further describe the current limitations, and comment on promising future strategies to overcome these limitations.

\section{Recent advances \\ BRAF inhibitors}

In 2002, it was discovered that cutaneous melanoma is a molecularly heterogeneous disease with approximately $40 \%$ to $60 \%$ harboring an activating mutation in the gene encoding for the serine/threonine kinase protein kinase B-raf (BRAF) with 90\% of the mutations resulting in a substitution of valine for glutamate at amino acid 600 (V600E) [5-8]. Mutated BRAF leads to constitutive activation of the mitogen-activated protein kinase pathway (MAPK) that in turn increases cellular proliferation and drives oncogenic activity. Given the relatively high incidence of mutant BRAF as well as its oncogenic potential, investigators have long sought to selectively inhibit mutated BRAF. Earlier attempts to inhibit BRAF in patients with melanoma with sorafenib were largely unsuccessful secondary to the poor sensitivity of sorafenib to selectively target mutant BRAF that led to intolerable off-target side effects through inhibition of wild- 
type BRAF and other off-target effects [9-13]. Recently, highly selective BRAF inhibitors capable of silencing mutant BRAF (V600E) with little effect on wild-type BRAF have emerged (Table 1). In a phase 1 study, the first of these selective BRAF inhibitors, vemurafenib, demonstrated substantial tumor regression in $81 \%$ of patients with metastatic melanoma who had a BRAF (V600E) mutation and received the recommended phase 2 dose [13,14]. The follow up phase 2 (BRIM2) study of previously treated patients demonstrated a confirmed response rate (RR) of $53 \%$ with a 6.8 month median duration of response [15]. Finally, a phase 3 randomized control trial (BRIM3) of previously untreated patients compared vemurafenib to dacarbazine demonstrating improvements in RR (48\% versus 5\%), progression free survival (5.3 versus 1.6 months), percent of patients alive at six months ( $84 \%$ versus $64 \%)$ with a $75 \%$ reduction in risk of death [16]. A second BRAF inhibitor, GSK2118436, showed similar efficacy in a phase $1 / 2$ study although OS data are not yet mature [17]. In addition, $10 \%$ to $30 \%$ of patients with a BRAF mutation have a non-V600E mutation with the most common nonV600E mutation being V600K which is present in 5\% to $20 \%$ of melanoma patients with a BRAF mutation $[7,18]$. Both vemurafenib and GSK2118436 have shown activity in V600K mutant melanomas and while vemurafenib is not currently approved for patients with V600K mutations, further studies are examining its efficacy in nonV600E mutant patients $[16,19]$. Finally, both vemurafenib and GSK2118436 have been tested in patients with brain metastasis with apparent activity in the brain although the number of treated patients remains small at present $[19,20]$. In summary, both highly selective BRAF inhibitors, vemurafenib and GSK2118436, have demonstrated excellent clinical activity with a high response rate and low toxicity in patients with BRAF V600E mutations but, unfortunately, both therapies are limited by a relatively short duration that averages around six months. The most important toxicity related to BRAF inhibitors is accelerated growth of cutaneous squamous cell carcinomas (SCC) and keratoacanthomas through paradoxical activation of MAPK signaling occurring in approximately $20 \%$ of patients [21].
Fortunately, these SCC are easily removed and cured through local excision.

\section{Ipilimumab}

Melanoma is characterized as one of the most immunogenic tumors due to the presence of tumor infiltrating lymphocytes in resected melanoma, occasional spontaneous regressions, and clinical responses to immune stimulation. The immunogenicity of melanoma has led investigators to study novel immune strategies to overcome tumor immune evasion. One mechanism by which $\mathrm{T}$ cells self-regulate their activation is through expression of cytotoxic T-lymphocyte-associated antigen 4 (CTLA-4). CTLA-4 functions as a negative co-stimulatory molecule for the $\mathrm{T}$ cell, and therapies that antagonize CTLA-4 remove the brakes from the $T$ cell leading to a net effect of $\mathrm{T}$ cell hyper-responsiveness [22]. Ipilimumab is a fully human IgG1 monoclonal antibody that blocks CTLA-4, thereby increasing T-cell activity and promoting antitumor activity [23]. Two phase 3 randomized clinical trials have evaluated ipilimumab in metastatic melanoma [23,24]. In the first trial of patients with previously treated unresectable stage III or IV melanoma, ipilimumab demonstrated an improved overall survival versus glycoprotein 100 peptide vaccine (gp100) (10.1 versus 6.4 months) [24]. In the second phase 3 trial in previously untreated patients with metastatic melanoma, ipilimumab plus dacarbazine demonstrated improvement in OS versus single agent dacarbazine (11.2 versus 9.2 months) [23]. In both phase 3 studies, the response rate, complete response (CR) and partial response (PR) was only $10 \%$ to $15 \%$ and the disease control rate (CR, PR, and stable disease (SD)) was approximately $30 \%$. In addition, the improvement in percent of patients alive at one and two years is consistently $10 \%$ better than the non-ipilimumab containing arms (Table 2). While the response rate and improvement in OS in ipilimumab is relatively modest, the toxicities of the therapy, including immune-related enterocolitis, hepatitis, and dermatitis, are highly manageable [24].

\section{Future strategies}

The recent success of both vemurafenib and ipilimumab instilled hope into physicians and patients with metastatic melanoma; however, the limitations of both

Table 1 Summary of BRAF inhibitor trials

\begin{tabular}{|c|c|c|c|c|c|c|}
\hline Trial & Patients & $\begin{array}{c}\mathrm{RR} \\
\%\end{array}$ & $\begin{array}{c}\text { PFS } \\
\text { (months) }\end{array}$ & $\begin{array}{c}\text { OS } \\
\text { (years) }\end{array}$ & $\begin{array}{l}\text { Number } \\
\text { (Patients) }\end{array}$ & Summary \\
\hline $\begin{array}{l}\text { Phase } 2 \\
\text { Ribas et al. } \\
\quad[15]\end{array}$ & $\begin{array}{l}\text { Vemurafenib in previously } \\
\text { treated metastatic melanoma }\end{array}$ & 52 & 6.2 & $\begin{array}{l}\text { Not yet } \\
\text { reached }\end{array}$ & 132 & $\begin{array}{l}\text { Met primary end point of best overall survival target of } 30 \% \\
\qquad(95 \% \mathrm{Cl} \text { : } 43 \text { to } 61 \%)\end{array}$ \\
\hline $\begin{array}{l}\text { Phase } 3 \\
\text { Chapman } \\
\text { et al. [16] }\end{array}$ & $\begin{array}{l}\text { Vemurafenib } \\
\text { versus } \\
\text { dacarbazine in untreated } \\
\text { metastatic melanoma }\end{array}$ & $\begin{array}{l}48 \\
\vee \\
5\end{array}$ & $\begin{array}{l}5.3 \\
\vee \\
1.6\end{array}$ & $\begin{array}{l}\text { Not yet } \\
\text { reached }\end{array}$ & 675 & $\begin{array}{l}\text { Compared vemurafenib and dacarbazine with co-primary } \\
\text { endpoints of overall survival and progression free survival. } \\
84 \% \text { vs } 64 \% \text { OS at } 6 \text { months ( } 95 \% \text { Cl: } 78 \text { to } 89 \text { ) }\end{array}$ \\
\hline
\end{tabular}

OS, overall survival; PFS, progression free survival; RR, response rate. 
Table 2 Summary of Ipilimumab Trials

\begin{tabular}{|c|c|c|c|c|c|c|}
\hline Trial & Patients & $\begin{array}{l}\mathrm{RR} \% \\
\text { (CR/ } \\
\mathrm{PR}) \\
\end{array}$ & $\begin{array}{c}\text { PFS } \\
\text { (months) }\end{array}$ & $\begin{array}{c}\text { OS } \\
\text { (years) }\end{array}$ & $\begin{array}{c}\text { Number } \\
\text { (patients) }\end{array}$ & Summary \\
\hline $\begin{array}{l}\text { Phase } 3 \\
\text { Hodi et } \\
\text { al. [24] }\end{array}$ & $\begin{array}{c}\text { Ipilimumab plus gp100 } \\
\text { versus } \\
\text { Ipilimumab alone } \\
\text { versus } \\
\text { gp100 alone } \\
\text { previously treated metastatic melanoma }\end{array}$ & $\begin{array}{l}5.7 \\
\text { versus } \\
10.9 \\
\text { versus } \\
1.5\end{array}$ & $\begin{array}{c}2.76 \\
\text { versus } \\
2.86 \\
\text { versus } \\
2.76\end{array}$ & $\begin{array}{l}10.0 \\
\text { versus } \\
10.1 \\
\text { versus } \\
6.4\end{array}$ & 676 & $\begin{array}{c}\text { Ipilimumab with significant improvement in OS } \\
\text { versus gp-100. }\end{array}$ \\
\hline $\begin{array}{l}\text { Phase } 3 \\
\text { Robert } \\
\text { et al. } \\
\text { [23] }\end{array}$ & $\begin{array}{c}\text { Ipilimumab plus dacarbazine } \\
\text { versus } \\
\text { dacarbazine in untreated metastatic melanoma }\end{array}$ & $\begin{array}{l}15.2 \\
\text { versus } \\
10.3\end{array}$ & $\begin{array}{c}\text { Not } \\
\text { stated }\end{array}$ & $\begin{array}{l}11.2 \\
\text { versus } \\
9.1\end{array}$ & 502 & $\begin{array}{l}\text { Ipilimumab plus dacarbazine significantly with } \\
\text { significant improvement in OS over dacarbazine. }\end{array}$ \\
\hline $\begin{array}{l}\text { Phase } 2 \\
\text { Hersh et } \\
\text { al. [40] }\end{array}$ & $\begin{array}{c}\text { Ipilimumab } \\
\text { versus } \\
\text { Ipilimumab plus dacarbazine in chemotherapy } \\
\text { naïve patients with metastatic melanoma }\end{array}$ & $\begin{array}{l}5.3 \\
\text { versus } \\
14.3\end{array}$ & $\begin{array}{l}\text { Not } \\
\text { stated }\end{array}$ & $\begin{array}{c}11.4 \\
\text { versus } \\
14.4\end{array}$ & 72 & $\begin{array}{l}\text { Ipilimumab plus dacarbazine improved RR and } \\
\text { OS compared to single agent ipilimumab. }\end{array}$ \\
\hline
\end{tabular}

$\mathrm{CR}$, complete response; OS, overall survival; PFS, progression free survival; $\mathrm{PR}$, partial response; $\mathrm{RR}$, response rate.

therapies emphasize the importance of developing novel treatment strategies. One of the major challenges in overcoming the limitations of these novel therapies is both increasing the duration of response to BRAF inhibitors and improving the response rate of ipilimumab. We will discuss multiple strategies to address the limitations of vemurafenib below.

\section{Overcoming resistance to BRAF inhibitors using additional targeted therapies}

While selective BRAF inhibitors have provided a major breakthrough in the treatment of melanoma, resistance to therapy invariably develops with the median duration of benefit of approximately six months (Figure 1). Mutant BRAF drives melanoma tumor proliferation through activation of the mitogen activated kinase pathway (MAP) pathway, and resistance to BRAF inhibitors has been described in both MAP kinase-dependent and -independent pathways [25-27]. MAP kinase-dependent pathways of resistance include secondary NRAS mutations, elevated expression of COT kinase, CRAF activation, and acquired MEK1 mutation [25,28-31]. MAP kinase-independent pathways include upregulation of PDGFR, additional receptor tyrosine kinases activation including AXL, ERBB4, and IGF1R, activation of PI3K/ AKT signaling, and loss of PTEN [25,29,31-35]. Strategies to overcoming these mechanisms of resistance are currently being developed. A recent phase $1 / 2$ study combining an oral MEK 1/2 inhibitor GSK1120212 with BRAF inhibitor GSK2118436 was well tolerated [36], but it is too early to determine if the combination will increase the duration of response of a single agent BRAF inhibitor. A randomized phase 3 study set to begin in 2012 will hopefully address this question. Additional future targeted combinations will likely include BRAF inhibitors with PI3K, PDGFR, IGF1R, MEK, or ERBB4 inhibitors and will be expanded upon below.

\section{Improving upon ipilimumab}

While ipilimumab is capable of inducing long-term responses in a minority of patients, the relatively low response rate $(10 \%$ to $15 \%)$ and meager improvement in median survival (two months) limit its utility. A key area of improving the clinical benefit of ipilimumab is to increase the response rate either through improved patient selection or through combination with other therapies. At present, there is no reliable predictor of benefit for ipilimumab. One group recently reported that the presence of a BRAF mutation does not predict clinical benefit of ipilimumab [37]. Other groups have shown that ipilimumab increases the frequency of $\mathrm{T}$ cells with inducible co-stimulatory molecule (ICOS) [38] and that ICOS $\mathrm{T}$ cells are necessary for response to ipilimumab [39]. Whether or not baseline ICOS T cells predict benefit to ipilimumab remains to be determined. Finally, there is ample evidence to suggest that a higher dose of ipilimumab $(10 \mathrm{mg} / \mathrm{kg})$ results in an increased response than the approved dose $(3 \mathrm{mg} / \mathrm{kg})$ and a randomized phase 3 study is underway to address this question.

In addition to improved patient identification, many investigators are combining ipilimumab with other treatment modalities in order to increase the response rate. As mentioned above, the phase 3 study of dacarbazine plus ipilimumab did not yield a higher than expected response rate; however, this study was not designed to answer this question. In a randomized phase 2 study of ipilimumab versus ipilimumab and dacarbazine, the ipilimumab/dacarbazine combination resulted in an increased response rate (15\% versus 5\%) and improved one-, two-, and three-year survival [40]. In a single arm phase 2 study, the combination of ipilimumab and temozolamide resulted in an overall disease control rate $(\mathrm{CR} / \mathrm{PR}$ and $\mathrm{SD})$ of $67 \%$ which is much higher than seen in single agent studies [41]. A phase 1 study testing the 


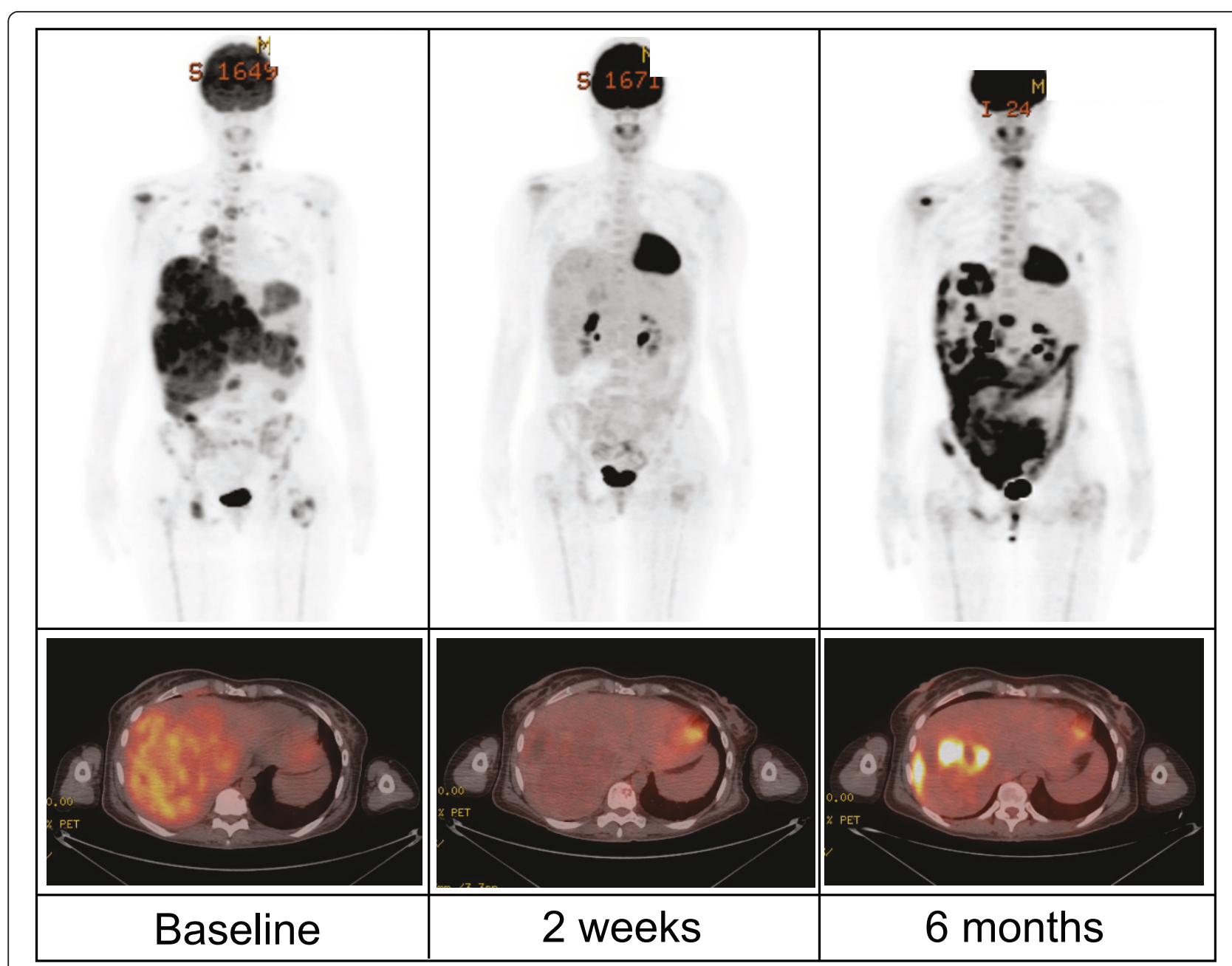

Figure 1 Typical response for patients on BRAF inhibitors. BRAF inhibitors can induce positron emission tomography (PET) responses in as little as two weeks but unfortunately most patients developed relapse and progressive disease at about six months. This patient was treated in the phase 1 study of PLX4032 (vemurafenib).

combination of ipilimumab and bevacizumab resulted in a RR of $36 \%$ and overall disease control rate of $67 \%$, but immune-related adverse reactions also seemed to be greatly enhanced with this combination [42]. Ipilimumab is also being combined with multiple other agents including granulocyte-macrophage colony-stimulating factor (GM-CSF), vaccines and other immune modulators with a goal to overcoming the immune tolerance of melanoma. In summary, there is no agent that is proven to increase the response rate of ipilimumab in a phase 3 trial and until that evidence exists, we do not recommend combining ipilimumab with any other therapy outside the setting of a clinical trial.

\section{Ipilimumab combined with radiation}

Finally, an additional area of research to improve on the success of ipilimumab is through the combination of ipilimumab with radiation therapy with two trials currently enrolling patients. The first is a pilot study of ipilimumab in stage IV melanoma patients who are receiving palliative radiation therapy [43]. The second is the RADVAX study, a stratified phase $1 / 2$ dose escalation trial of stereotactic body radiotherapy followed by ipilimumab in patients with metastatic melanoma [43]. The toxicity profile of this combination therapy will be of interest as both therapies can elicit similar toxicities such as colitis [44]. Trials combining vemurafenib and radiation therapy are also in the planning phases.

\section{Additional targeted therapies}

As mentioned above, approximately $50 \%$ of patients with melanoma harbor BRAF mutations and are eligible for treatment with the novel BRAF inhibitors. In addition to BRAF, other mutations in genes as well as alterations in cancer related pathways have been identified in 
patients with melanoma, thereby leading investigators to target these pathways as well.

c-kit, also known as CD117, is a receptor tyrosine kinase that is mutated in approximately $20 \%$ of acral, mucosal, and chronically sun-damaged skin [45]. The ligand for KIT is stem cell factor (SCF) and binding of SCF to c-kit induces activation of downstream signaling pathways that are involved in mediating growth and survival signals within the cell including the P13K-AKT-mTOR pathway and the RAS-RAF-MEK-ERK pathway. KIT has been implicated in the pathogenesis of several cancers including acute myeloid leukemia and gastrointestinal stromal tumors (GIST) [46-49]. Unlike in GIST where c-kit mutations tend to be deletions or insertions in exon 11, c-kit mutations in melanoma occur at multiple sites along the gene including both the juxta-membrane domain at exon 11 and exon 13 and the kinase domain at exon 17 and are usually point mutations that do not correlate with KIT copy number or CD117 expression [50,51].

Imatinib, an oral tyrosine kinase inhibitor with known activity against c-kit activated tumors, was tested in three phase 2 studies of patients with melanomas that harbor ckit mutations [52-54]. The first study enrolled patients with metastatic melanoma who expressed at least one protein tyrosine kinase (c-kit, platelet derived growth factor receptors, $\mathrm{c}-\mathrm{abl}$, or abl related gene) demonstrating a response in only one patient, interestingly in the patient who had the highest level of c-kit expression [52]. Of note, mutations in c-kit were not required prior to entry in this study. In the second study, 28 patients with c-kit mutations and amplifications with advanced unresectable melanoma arising from acral, mucosal, and chronically sundamaged sites were treated with imatinib mesylate $400 \mathrm{mg}$ orally twice daily in six-week cycles until disease progression or unacceptable toxicity [54]. Durable overall response rate (ORR) was $16 \%$ with a median time to progression of 12 weeks and median OS of 46.3 weeks. The third study enrolled 43 patients with c-kit mutated metastatic melanoma treated with imatinib who demonstrated an ORR of $23.3 \%$ and median OS of 14 months, with $51 \%$ alive at one year [53]. Please see Table 3 for a summary of these three trials. In summary, the responses to imatinib were primarily demonstrated in patients harboring mutations in c-kit at exon 11 or exon 13. Activity of dasatinib in c-kit mutated melanoma has already been demonstrated and additional trials with imatinib, nilotinib, and dasatinib are currently ongoing $[43,50,55]$. As is the case with the BRAF inhibitors, combinations of c-kit inhibitors with cyotoxic agents, immunotherapies, and other targeted therapies are underway.

\section{ERBB4}

ERBB4 (HER4) is a protein tyrosine kinase that activates both the ERK and AKT signaling pathways [56,57]. In a genome wide search of the tyrosine kinome, ERBB4 mutations were identified in $19 \%$ of patients with melanoma. In vitro assays demonstrated that lapatinib, a pan-ERBB inhibitor had activity in cell lines with these mutations and not in cell lines without these mutations [58]. In this same study, it was noted the ERBB4 mutations were found in patients with and without BRAF mutations suggesting that ERBB4 is perhaps an independent and complementary driver of tumorigenesis. A phase 2 trial of lapatanib in stage IV melanoma patients who harbor an ERBB4 mutation is currently enrolling [43]. Future therapeutic combinations of lapatinib and other ERBB4 inhibitors with either other targeted, immune, or chemotherapeutic agents hold promise.

\section{VEGF}

Vascular endothelial growth factor (VEGF) as a mediator of tumor associated angiogenesis plays an essential role in the progression of melanoma [59]. The vascular radial and vertical growth patterns of melanoma are associated with rapid progression and metastasis, indicative of a therapeutic role for VEGF inhibition [60]. As single agents, anti-VEGF therapies have not demonstrated much success in patients with metastatic melanoma, but when combined with chemotherapy and immunotherapy there is some hint that anti-VEGF therapy has a future in the treatment of patients with metastatic melanoma. In a single arm phase 2 study of carboplatin, paclitaxel, and bevacizumab in patients with stage IV melanoma the RR was $17 \%$ with a median progression free survival (PFS) of six months and median OS of 12 months [61]; however, a randomized phase 2 trial of carboplatin and paclitaxel plus or minus bevacizumab failed to demonstrated significant improvement in OS (12.3 versus 8.6, $P=0.17$ ) [62]. A single arm phase 2 study in chemotherapy naïve (CN) patients and previously treated (PT) patients tested the combination of bevacizumab with nab-paclitaxel and carboplatin and demonstrated a RR of $25.6 \%(\mathrm{CN})$ and $8.8 \%$ (PT) with median PFS of $4.5(\mathrm{CN})$ months and 4.1 (PT) months and OS of 11.1 (CN) months and 10.1 (PT) months [63]. This combination is moving forward for a phase 3 evaluation. A multi-center phase 2 study of axitinib, an oral second-generation inhibitor of VEGF receptor-1, 2, and 3 demonstrated a RR of $19 \%$ with a median PFS of 3.9 months and median OS of 6.6 months [64]. In addition, a separate VEGF receptor-1, 2, and 3 inhibitor, E7080 or lenvatinib, demonstrated a RR of $21 \%$ in phase 1 evaluation of patients with solid tumors including patients with melanoma [65]. Taken together, inhibiting the VEGF pathway is likely beneficial for a subset of patients and improved patient selection combined will hopefully lead to clinically meaningful improvements in patient outcomes. Please see Table 4 summarizing the above trials involving VEGF in melanoma. 
Table 3 Summary of C-KIT Trials

\begin{tabular}{|c|c|c|c|c|c|c|}
\hline Trial & Patients & $\begin{array}{l}\mathrm{RR} \% \\
(\mathrm{CR} / \\
\mathrm{PR}) \\
\end{array}$ & $\begin{array}{c}\text { PFS } \\
\text { (month) }\end{array}$ & OS & $\begin{array}{l}\text { Number } \\
\text { (patients) }\end{array}$ & Summary \\
\hline $\begin{array}{l}\text { Single } \\
\text { Arm } \\
\text { Phase } 2 \\
\text { Kim KB } \\
\text { et al. [52] }\end{array}$ & $\begin{array}{l}\text { Imatinib mesylate } 400 \mathrm{mg} \text { bid } \\
\text { in advanced unresectable } \\
\text { melanoma }\end{array}$ & $5 \%$ & 1.4 & $\begin{array}{c}7.5 \\
\text { months }\end{array}$ & 21 & $\begin{array}{c}\text { Imatinib mesylate demonstrated a response in } 1 \text { patient who } \\
\text { also had high c-kit expression and alternate splicing variant in c- } \\
\text { kit mRNA transcript. }\end{array}$ \\
\hline $\begin{array}{l}\text { Single } \\
\text { Arm } \\
\text { Phase } 2 \\
\text { Carvajal } \\
\text { et al. [54] }\end{array}$ & $\begin{array}{l}\text { Imatinib mesylate } 400 \mathrm{mg} \text { bid } \\
\text { in advanced unresectable } \\
\text { melanoma }\end{array}$ & $16 \%$ & 3 & $\begin{array}{c}46.3 \\
\text { weeks }\end{array}$ & 28 & $\begin{array}{l}\text { Imatinib mesylate demonstrated a significant clinical response in } \\
\text { subset of patients with cKit mutation and advanced melanoma }\end{array}$ \\
\hline $\begin{array}{l}\text { Single } \\
\text { Arm } \\
\text { Phase } 2 \\
\text { Guo et } \\
\text { al. [53] }\end{array}$ & $\begin{array}{l}\text { Imatinib mesylate } 400 \mathrm{mg} \text { daily } \\
\text { in metastatic melanoma }\end{array}$ & $23.3 \%$ & 3.5 & $\begin{array}{c}14 \\
\text { months }\end{array}$ & 43 & $\begin{array}{l}\text { Imatinib mesylate demonstrated a significant clinical response in } \\
\text { a subset of patients with cKit mutation and metastatic } \\
\text { melanoma }\end{array}$ \\
\hline
\end{tabular}

athe clustering of responses in both trials were seen in patients harboring c-kit mutations at exon 11 or exon 13; c-kit overexpression on IHC without a mutation did not correlate with a response. CR, complete response; OS, overall survival; PFS, progression free survival; PR, partial response; RR, response rate.

\section{Future of immunotherapy \\ $P D-1 / P D-L 1$}

One mechanism by which melanoma is thought to evade the immune system is through tumor expression of programmed death ligand 1 (PD-L1). PD-L1 is a negative regulator of the immune system that acts through binding of the PD-1 present on activated lymphocytes and PD-L1/PD-1 interaction causes immune tolerance through apoptosis of the activated lymphocyte [66-68]. MDX-1106 is a genetically engineered fully human immunoglobulin G4 monoclonal antibody specific for human PD-1 [69]. A phase 1 study of anti-PD-1 antibody, MDX-1106, demonstrated single agent responses in a variety of previously treated, refractory solid tumors including melanoma with few treatment- related immune toxicities [69]. The clinical experience with anti-PD1 treatment is limited but encouraging and a dose escalation study of the combination of MDX1106 and ipilimumab is currently recruiting [43]. In addition to antibodies that target PD-1, phase 1 trials of anti-PD-L1 are also underway.

\section{Adoptive $T$ cell therapy}

The presence of tumor infiltrating lymphocytes (TIL) in resected melanoma samples is one of the reasons melanoma is often characterized as an immunogenic malignancy. Attempts to isolate, expand and infuse TIL for the treatment of cancer is termed adoptive cell therapy (ACT) and has shown promise for the treatment of patients with metastatic melanoma [70-73]. Early studies using TIL and IL- 2 produced a response rate of $34 \%$.

Table 4 Summary of VEGF Trials

\begin{tabular}{|c|c|c|c|c|c|c|}
\hline Trial & Patients & $\begin{array}{l}\mathrm{RR} \% \\
(\mathrm{CR} / \\
\mathrm{PR})\end{array}$ & $\begin{array}{c}\text { PFS } \\
\text { (months) }\end{array}$ & $\begin{array}{c}\text { OS } \\
\text { (months) }\end{array}$ & $\begin{array}{c}\text { Number } \\
\text { (patients) }\end{array}$ & Summary \\
\hline $\begin{array}{l}\text { Single Arm } \\
\text { Phase } 2 \\
\text { Perez et al. } \\
\text { [61] }\end{array}$ & $\begin{array}{l}\text { Carboplatin plus paclitaxel and bevacizumab } \\
\text { in unresectable metastatic melanoma }\end{array}$ & 17 & 6 & 12 & 53 & $\begin{array}{c}\text { Carboplatin plus paclitaxel and } \\
\text { bevacizumab was well tolerated and } \\
\text { clinically beneficial }\end{array}$ \\
\hline $\begin{array}{l}\text { Randomized } \\
\text { Phase } 2 \\
\text { Kim et al. } \\
\text { [62] }\end{array}$ & $\begin{array}{c}\text { Carboplatin plus paclitaxel and bevacizumab } \\
\text { versus } \\
\text { Carboplatin plus paclitaxel in untreated } \\
\text { metastatic melanoma }\end{array}$ & $\begin{array}{l}25.5 \\
\text { versus } \\
16.4\end{array}$ & $\begin{array}{l}5.6 \\
\text { versus } \\
4.2\end{array}$ & $\begin{array}{l}12.3 \\
\text { versus } \\
8.6\end{array}$ & 214 & $\begin{array}{c}\text { Carboplatin plus paclitaxel and } \\
\text { bevacizumab demonstrated statistically } \\
\text { significant improvement in OS }\end{array}$ \\
\hline $\begin{array}{l}\text { Single Arm } \\
\text { Phase } 2 \\
\text { Kottschade } \\
\text { et al. [63] }\end{array}$ & $\begin{array}{l}\text { Carboplatin plus nab-paclitaxel in } \\
\text { chemotherapy naïve }(\mathrm{CN}) \text { and previously } \\
\text { treated (PT) metastatic melanoma }\end{array}$ & $\begin{array}{l}25.6 \\
(\mathrm{CN}) \\
8.8 \\
(\mathrm{PT})\end{array}$ & $\begin{array}{l}4.5(\mathrm{CN}) \\
4.1(\mathrm{PT})\end{array}$ & $\begin{array}{l}11.1(\mathrm{CN}) \\
10.1(\mathrm{PT})\end{array}$ & $\begin{array}{l}41(\mathrm{CN}) \\
35(\mathrm{PT})\end{array}$ & $\begin{array}{l}\text { Carboplatin plus nab-paclitaxel has clinical } \\
\text { activity in chemotherapy naïve patients }\end{array}$ \\
\hline $\begin{array}{l}\text { Single Arm } \\
\text { Phase } 2 \\
\text { Fruehauf et } \\
\text { al. [64] }\end{array}$ & $\begin{array}{c}\text { Axitinib }{ }^{a} \text { in metastatic melanoma after } \\
\text { maximum on one prior therapy }\end{array}$ & $18.8 \%$ & 3.9 & 6.6 & 32 & $\begin{array}{c}\text { Axitinib demonstrated clinical activity in } \\
\text { metastatic melanoma. }\end{array}$ \\
\hline
\end{tabular}

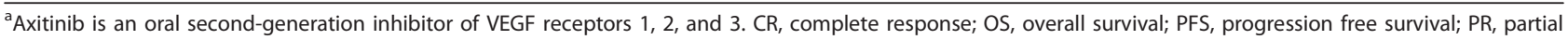
response $\mathrm{RR}$, response rate. 
Later studies using nonmyeloblative lymphodepletion with cytotoxic chemotherapy, with or without total body irradiation, induced response rates as high as $72 \%$ [70-75]. One of the limitations of ACT is that TIL expansion is not possible for all patients although it was recently reported that TIL is successfully generated in > $60 \%$ of all patients with melanoma and this figure is even higher in patients who did not receive prior chemotherapy [76]. In order to circumvent the process of tumor resection and isolation of TIL, investigators have developed methods to genetically modify autologous peripheral $\mathrm{T}$ cells to express a $\mathrm{T}$ cell receptor that targets melanoma antigens. This approach has induced a response rate in a subset of patients with melanoma and a similar approach has also yielded results in patients with refractory chronic lymphocytic leukemia [77]. In summary, ACT for the treatment of melanoma is a promising, albeit resource consuming method for the treatment of metastatic melanoma.

\section{Interleukin-2}

With the approval of ipilimumab, the role of HD IL-2 remains in question. While the clinical benefit of HD IL-2 is roughly similar to ipilimumab, the toxicity is worse and tolerability is less. Multiple strategies have attempted to identify biomarkers to predict clinical benefit of HD IL-2. Recently, a retrospective study found that patients with an NRAS mutation have a higher likelihood to respond to HD IL-2 [78]. In addition, a prospective study of patients with metastatic melanoma and renal cell carcinoma found that elevated pre-treatment serum VEGF and fibronectin are inversely correlated with the response rate to HD-IL-2 [79]. Both of these findings require further study at additional centers before changing clinical practice. Multiple efforts to increase the response rate of HD IL-2 while maintaining the duration of response have been attempted. The addition of a peptide vaccine (gp100) to HD IL-2 demonstrated an improved objective response rate $(16 \%$ versus $6 \%, P=0.03)$ and overall survival (17.8 versus 11.1 months, $P=0.06$ ) [80]. There are plans to improve upon this finding by using more potent vaccines.

Finally, it is becoming more evident that patients who progress on HD IL-2 do derive clinical benefit from ipilimumab. In the phase 3 study of previously treated patients, patients who progressed on prior HD-IL- 2 received a similar benefit to ipilimumab as those who did not [24]. Similarly, a retrospective study analyzing patients who progressed on HD IL-2 and then received ipilimumab had a response rate (19\%) and OS (12 months) to ipilimumab that was similar to previously reported historical controls [81]. Given the lack of approved agents and the limited but quantifiable benefit, we believe there still remains a role for HD IL-2 in patients who are fit enough to receive it.

\section{Combined immune and targeted therapy}

As we learn more about the molecular pathways and immune modulation of melanoma, novel combinations of immune and targeted therapies have the potential of overcoming the low response rates of immune therapy and the short durations of response in targeted therapies. Pre-clinical work has suggested that BRAF inhibition leads to increased tumor recognition by $\mathrm{T}$-cells providing a rational for the combination of BRAF inhibitors with agents that stimulate the immune system such as ipilimumab [82]. In addition, BRAF inhibitors and other targeted therapies will likely be combined with ipilimumab, IL-2, anti-PD-1, and other immunotherapies that are currently being tested.

\section{Role of surgery in metastatic disease}

Patients with oligometastatic disease present a clinical dilemma of whether to treat systemically or locally. Highly selected patients with isolated lung or liver metastasis, good performance status, and less aggressive tumor biology have benefited from metastasectomy with improved five-year survival rates and median OS rates of 20 to 25 months [83-87]. Again, patient selection is the key for success in this setting. A recent phase 2 study enrolled 77 patients for complete resection of metastatic disease and demonstrated a relapsed free survival of five months and $36 \%$ of patients alive at three years [88]. While this trial demonstrates that long-term survival can be achieved through surgery, the trial did not further identify patients more likely to benefit from surgery. Currently, a prospective trial of patients with oligometastatic disease is randomizing patients to either surgery versus systemic therapy. This will hopefully shed more light on which patients are most likely to benefit from metastasectomy.

\section{Conclusions}

In 2011, the FDA approval of vemurafenib and ipilimumab instilled optimism in clinicians treating patients with metastatic melanoma. While these therapies have limitations, many promising strategies exist to overcome these limitations. Understanding and overcoming resistance pathways, combining current and future agents, identifying biomarkers to improve patient selection, and discovering future therapeutic targets will hopefully lead to further treatment advances.

\section{Abbreviations}

ACT: Adoptive cell therapy; CN: chemotherapy naïve; CR: complete response; CTLA4: cytotoxic T-lymphocyte-associated antigen 4; GIST: gastrointestinal stromal tumors; Gp100: glycoprotein 100 peptide vaccine; GM-CSF: 
granulocyte-macrophage colony-stimulating factor; HD IL-2: high dose IL-2; ICOS: inducible co-stimulatory molecule; MAP: mitogen activated kinase pathway; ORR: overall response rate; OS: overall survival; PR: partial response; PT: previously treated; PD-L1: programmed death ligand 1; PFS: progression free survival; RR: response rate; SCC: squamous cell carcinoma; SD: stable disease; SCF: stem cell factor; TIL: tumor infiltrating lymphocytes; VEGF: vascular endothelial growth factor.

\section{Author details}

'Division of Hematology and Oncology, Mayo Clinic Florida, 4500 San Pablo Road, Jacksonville, FL 32224, USA. 'Division of Hematology and Oncology, Mayo Clinic Rochester, Gonda Building 10 South, Rochester, MN 55905, USA.

\section{Authors' contributions}

LF wrote the initial version of the manuscript. SM critically reviewed the manuscript. RJ conceived the outline of the manuscript, reviewed the manuscript, and made final changes. All authors read and approved the final manuscript.

\section{Authors' information}

LF is a fellow in Hematology and Oncology at Mayo Clinic Florida. SM is a Professor of Medicine and Oncology at Mayo Clinic Rochester with a clinical and research focus on melanoma. RJ is a Clinical Instructor at Mayo Clinic Florida with a clinical and research focus on melanoma and genitourinary malignancies.

\section{Competing interests}

The authors declare that they have no competing interests.

Received: 9 November 2011 Accepted: 2 March 2012

Published: 2 March 2012

\section{References}

1. Jemal A, Siegel R, Xu J, Ward E: Cancer statistics, 2010. CA: Cancer Journal for Clinicians 2010, 60:277-300.

2. Hill G, Krementz E, Hill H: Dimethyl triazeno imidazole carboxamide and combination therapy for melanoma. Cancer 1984, 53:1299-1305.

3. Atkins $M$, Lotze $M$, Dutcher J, Fisher R: High-dose recombinant interleukin2 therapy for patients with metastatic melanoma: analysis of 270 patients treated between 1985 and 1993. Journal of Clinical Oncology 1999, 17(7):2105-2116.

4. Phan G, Attia P, Steinberg S, White D: Factors associated with response to high-dose interleukin-2 in patients with metastatic melanoma. Journal of Clinical Oncology 2001, 19(15):3477-3482.

5. Davies H, Bignell G, Cox C, Stephens P: Mutations of the BRAF gene in human cancer. Nature 2002, 417.

6. Curtin J, Fridyland J, Kageshita T, Patel H: Distinct sets of genetic alterations in melanoma. New England Journal of Medicine 2005, 353(20):2135-2147.

7. Si L, Kong Y, Xu X, Flaherty KT, Sheng X, Cui C, Chi Z, Li S, Mao L, Guo J: Prevalence of BRAF V600E mutation in Chinese melanoma patients: Large scale analysis of BRAF and NRAS mutations in a 432-case cohort. European journal of cancer 2011.

8. Jakob JA, Bassett RL, Ng CS, Lazar AJF, Alvarado GC, Rohlfs ML, Richard J, Gershenwald JE, Hwu P, Kim KB, et al: Clinical characteristics and outcomes associated with BRAF and NRAS mutations in metastatic melanoma. Cancer 2011.

9. Wilhelm SM, Carter C, Tang L, Wilkie D, McNabola A, Rong H, Chen C, Zhang $X$, Vincent P, McHugh M, et al: BAY 43-9006 Exhibits Broad Spectrum Oral Antitumor Activity and Targets the RAF/MEK/ERK Pathway and Receptor Tyrosine Kinases Involved in Tumor Progression and Angiogenesis. Cancer Res 2004, 64(19):7099-7109.

10. Eisen T, Ahmad T, Flaherty KT, Gore M, Kaye S, Marais R, Gibbens I, Hackett $\mathrm{S}$, James M, Schuchter LM, et al: Sorafenib in advanced melanoma: a Phase II randomised discontinuation trial analysis. $\mathrm{Br} J$ Cancer 2006, 95(5):581-586.

11. McDermott DF, Sosman JA, Gonzalez R, Hodi FS, Linette GP, Richards J, Jakub JW, Beeram M, Tarantolo S, Agarwala S, et al: Double-blind randomized phase II study of the combination of sorafenib and dacarbazine in patients with advanced melanoma: a report from the
11715 Study Group. Journal of clinical oncology: official journal of the American Society of Clinical Oncology 2008, 26(13):2178-2185.

12. Hauschild A, Agarwala SS, Trefzer U, Hogg D, Robert C, Hersey P, Eggermont A, Grabbe S, Gonzalez R, Gille J, et al: Results of a Phase III, Randomized, Placebo-Controlled Study of Sorafenib in Combination With Carboplatin and Paclitaxel As Second-Line Treatment in Patients With Unresectable Stage III or Stage IV Melanoma. J Clin Oncol 2009, 27(17):2823-2830.

13. Flaherty KT, Puzanov I, Kim KB, Ribas A, McArthur GA, Sosman JA, O'Dwyer PJ, Lee RJ, Grippo JF, Nolop K, et al: Inhibition of Mutated Activated BRAF in Metastatic Melanoma. New England Journal of Medicine 2010, 363(9):809-819.

14. Smalley K, Sondak V: Melanoma-an unlikely poster child for personalized cancer therapy. New England Journal of Medicine 2010, 363(9).

15. Ribas A, Kim K, Schuchter L, Gonzalez A: BRIM-2: an open label, multicenter phase II study of vemurafenib in previously treated patients with BRAF V600E mutation-positive metastatic melanoma. Journal of CLinical Oncology, 2011 ASCO Annual Meeting Proceedings 2011, 29(15s):8509.

16. Chapman PB, Hauschild A, Robert C, Haanen JB, Ascierto P, Larkin J, Dummer R, Garbe C, Testori A, Maio M, et al: Improved survival with vemurafenib in melanoma with BRAF V600E mutation. The New England journal of medicine 2011, 364(26):2507-2516.

17. Kefford R, Arkenau H, Brown M, Millward M: Phase I/ll study of GSK2118436, a selective inhibitor of oncogenic mutant BRAF kinase, in patients with metastatic melanoma and other solid tumors. Journal of CLinical Oncology, 2010 ASCO Annual Meeting Proceedings 2010, 28(15s):8503.

18. Menzies AMLV, Chatfield MDMS, Carlino JR, Howle RA, Scolyer JF, Thompson RF, Kefford GV, Long : BRAF mutation by age-decade and body mass index in metastatic melanoma. Journal of Clinical Oncology 2011, 29, 2011 (suppl; abstr 8507).

19. Long GVKR, Carr PJA, et al: Phase $1 / 2$ study of GSK2118436, a selective inhibitor of V600 mutant (Mut) BRAF kinase: evidence of activity in melanoma brain metastases (Mets). Ann Oncol 2010, 21, LBA27 [abstr].

20. Dummer RJR, Goldinger SM, Wagner I, Mitchell L, Veronese ML, Nick S, Hilfiker P, Gobbi S: An open-label pilot study of vemurafenib in previously treated metastatic melanoma patients with brain metastases. J Clin Oncol 2011, 29, (suppl; abstr 8548) 2011.

21. Su F, Viros A, Milagre C, Trunzer K, Bollag G, Spleiss O, Reis-Filho JS, Kong X, Koya RC, Flaherty KT, et al: RAS Mutations in Cutaneous Squamous-Cell Carcinomas in Patients Treated with BRAF Inhibitors. New England Journal of Medicine 2012, 366(3):207-215.

22. Melero I, Hervas-Stubbs S, Glennie M, Pardoll DM, Chen L: Immunostimulatory monoclonal antibodies for cancer therapy. Nature reviews Cancer 2007, 7(2):95-106.

23. Robert C, Thomas L, Bondarenko I, O'Day S, M DJ, Garbe C, Lebbe C, Baurain JF, Testori A, Grob JJ, et al: Ipilimumab plus dacarbazine for previously untreated metastatic melanoma. The New England journal of medicine 2011, 364(26):2517-2526

24. Hodi FS, O'Day SJ, McDermott DF, Weber RW, Sosman JA, Haanen JB, Gonzalez R, Robert C, Schadendorf D, Hassel JC, et al: Improved survival with ipilimumab in patients with metastatic melanoma. The New England journal of medicine 2010, 363(8):711-723.

25. Wagle N, Emery C, Berger MF, Davis MJ, Sawyer A, Pochanard P, Kehoe SM, Johannessen CM, MacConaill LE, Hahn WC, et al: Dissecting Therapeutic Resistance to RAF Inhibition in Melanoma by Tumor Genomic Profiling. Journal of Clinical Oncology 2011, 29(22):3085-3096.

26. Gorre ME, Mohammed M, Ellwood K, Hsu N, Paquette R, Rao PN, Sawyers CL: Clinical resistance to STI-571 cancer therapy caused by BCRABL gene mutation or amplification. Science 2001, 293(5531):876-880.

27. Ellis LM, Hicklin DJ: Resistance to Targeted Therapies: Refining Anticancer Therapy in the Era of Molecular Oncology. Clin Cancer Res 2009, 15(24):7471-7478.

28. Nazarian R, Shi H, Wang Q, Kong X, Koya RC, Lee H, Chen Z, Lee MK, Attar $\mathrm{N}$, Sazegar $\mathrm{H}$, et al: Melanomas acquire resistance to B-RAF(V600E) inhibition by RTK or N-RAS upregulation. Nature 2010, 468(7326):973-977.

29. Johannessen CM, Boehm JS, Kim SY, Thomas SR, Wardwell L, Johnson LA, Emery CM, Stransky N, Cogdill AP, Barretina J, et al: COT drives resistance to RAF inhibition through MAP kinase pathway reactivation. Nature 2010, 468(7326):968-972. 
30. Montagut C, Sharma SV, Shioda T, McDermott U, Ulman M, Ulkus LE, DiasSantagata D, Stubbs H, Lee DY, Singh A, et al: Elevated CRAF as a potential mechanism of acquired resistance to BRAF inhibition in melanoma. Cancer Res 2008, 68(12):4853-4861.

31. Villanueva J, Vultur A, Lee JT, Somasundaram R, Fukunaga-Kalabis M, Cipolla AK, Wubbenhorst B, Xu X, Gimotty PA, Kee D, et al: Acquired resistance to BRAF inhibitors mediated by a RAF kinase switch in melanoma can be overcome by cotargeting MEK and IGF-1R/PI3K. Cancer Cell 2010, 18(6):683-695.

32. Turke $A B$, Zejnullahu $K$, Wu $Y L$, Song $Y$, Dias-Santagata $D$, Lifshits $E$, Toschi $L$, Rogers A, Mok T, Sequist L, et al: Preexistence and clonal selection of MET amplification in EGFR mutant NSCLC. Cancer Cell 2010, 17(1):77-88.

33. Engelman JA, Zejnullahu K, Mitsudomi T, Song Y, Hyland C, Park JO, Lindeman N, Gale CM, Zhao X, Christensen J, et al: MET amplification leads to gefitinib resistance in lung cancer by activating ERBB3 signaling. Science 2007, 316(5827):1039-1043.

34. Guix M, Faber AC, Wang SE, Olivares MG, Song Y, Qu S, Rinehart C, Seidel B, Yee $D$, Arteaga $C L$, et al: Acquired resistance to EGFR tyrosine kinase inhibitors in cancer cells is mediated by loss of IGF-binding proteins. J Clin Invest 2008, 118(7):2609-2619.

35. Paraiso KH, Xiang Y, Rebecca WW, Abel EV, Chen YA, Munko AC, Wood E, Fedorenko IV, Sondak VK, Anderson AR, et al: PTEN loss confers BRAF inhibitor resistance to melanoma cells through the suppression of BIM expression. Cancer Res 2011, 71(7):2750-2760.

36. Infante JR, Falchook GS, Lawrence DP, Weber JS: Phase I/II study to assess safety, pharmacokinetics, and efficacy of the oral MEK $1 / 2$ inhibitor GSK1120212 dosed in combination with oral BRAF inhibitor. Journal of CLinical Oncology, 2011 ASCO Annual Meeting Proceedings 2011, 29(18s).

37. Jackson JGW, Hamid O, Schmidt H, Chasalow SD, Alaparthy S, Bao Y, Shahabi V: Assessment of association between BRAF mutation status in melanoma tumors and response to ipilimumab. J Clin Oncol 2011, 29, 2011 (suppl; abstr 2587).

38. Chen H, Liakou Cl, Kamat A, Pettaway C, Ward JF, Tang DN, Sun J, Jungbluth AA, Troncoso P, Logothetis $C$, et al: Anti-CTLA-4 therapy results in higher CD4+ICOShi T cell frequency and IFN-gamma levels in both nonmalignant and malignant prostate tissues. Proc Natl Acad Sci USA 2009, 106(8):2729-2734.

39. $\mathrm{Fu} T$, He Q, Sharma P: The ICOS/ICOSL pathway is required for optimal antitumor responses mediated by anti-CTLA-4 therapy. Cancer research 2011, 71(16):5445-5454.

40. Hersh EM, O'Day SJ, Powderly J, Khan KD, Pavlick AC, Cranmer LD, Samlowski WE, Nichol GM, Yellin MJ, Weber JS: A phase II multicenter study of ipilimumab with or without dacarbazine in chemotherapy-naive patients with advanced melanoma. Invest New Drugs 2011, 29(3):489-498.

41. Patel SP, Bedikian AY, Papadopoulos NE, Hwu W, Kim KB, Homsi J, Davies MA, Woodman SE, Radvanyi LG, Woodard K, et al: Ipilimumab plus temozolomide in metastatic melanoma. ASCO Meeting Abstracts 2011, 29(15_suppl):8579.

42. Hodi FS, Friedlander PA, Atkins MB, McDermott DF, Lawrence DP, Ibrahim N, Wu X, Zhou J, Giobbie-Hurder A, Murphy G, et al: A phase I trial of ipilimumab plus bevacizumab in patients with unresectable stage III or stage IV melanoma. ASCO Meeting Abstracts 2011, 29(15_suppl):8511.

43. ClinicalTrials.gov. [http://www.clinicaltrials.gov].

44. Lord J, Hackman R, Moklebust A, Thompson J, Higano C, Chielens D, Steinbach G, McDonald G: Refractory Colitis Following Anti-CTLA4 Antibody Therapy: Analysis of Mucosal FOXP3\&lt;sup\&gt;+\&lt;/sup\&gt; T Cells. Dig Dis Sci 2010, 55(5):1396-1405.

45. Curtin JA, Busam K, Pinkel D, Bastian BC: Somatic activation of KIT in distinct subtypes of melanoma. J Clin Oncol 2006, 24(26):4340-4346.

46. Hirota S, Isozaki K, Moriyama Y, Hashimoto K, Nishida T, Ishiguro S, Kawano K, Hanada M, Kurata A, Takeda M, et al: Gain-of-function mutations of c-kit in human gastrointestinal stromal tumors. Science 1998, 279(5350):577-580

47. Hirota S, Nishida T, Isozaki K, Taniguchi M, Nakamura J, Okazaki T, Kitamura Y: Gain-of-function mutation at the extracellular domain of KIT in gastrointestinal stromal tumours. J Pathol 2001, 193(4):505-510.

48. Kitayama H, Kanakura Y, Furitsu T, Tsujimura T, Oritani K, Ikeda H, Sugahara $H$, Mitsui $H$, Kanayama $Y$, Kitamura $Y$, et al: Constitutively activating mutations of c-kit receptor tyrosine kinase confer factorindependent growth and tumorigenicity of factor-dependent hematopoietic cell lines. Blood 1995, 85(3):790-798.
49. Wakita S, Yamaguchi H, Miyake K, Mitamura Y, Kosaka F, Dan K, Inokuchi K: Importance of c-kit mutation detection method sensitivity in prognostic analyses of $\mathrm{t}(8 ; 21)(\mathrm{q} 22 ; \mathrm{q} 22)$ acute myeloid leukemia. Leukemia 2011, 25(9):1423-1432.

50. Woodman SE, Trent JC, Stemke-Hale K, Lazar AJ, Pricl S, Pavan GM, Fermeglia M, Gopal YN, Yang D, Podoloff DA, et al: Activity of dasatinib against L576P KIT mutant melanoma: molecular, cellular, and clinical correlates. Mol Cancer Ther 2009, 8(8):2079-2085.

51. Beadling C, Jacobson-Dunlop E, Hodi FS, Le C, Warrick A, Patterson J, Town A, Harlow A, Cruz F, Azar S, et al: KIT gene mutations and copy number in melanoma subtypes. Clin Cancer Res 2008, 14(21):6821-6828.

52. Kim KB, Eton O, Davis DW, Frazier ML, McConkey DJ, Diwan AH, Papadopoulos NE, Bedikian AY, Camacho LH, Ross MI, et al: Phase II trial of imatinib mesylate in patients with metastatic melanoma. $\mathrm{Br} J$ Cancer 2008, 99(5):734-740.

53. Guo J, Si L, Kong Y, Flaherty KT, Xu X, Zhu Y, Corless CL, Li L, Li H, Sheng X, et al: Phase II, open-label, single-arm trial of imatinib mesylate in patients with metastatic melanoma harboring c-Kit mutation or amplification. Journal of clinical oncology: official journal of the American Society of Clinical Oncology 2011, 29(21):2904-2909.

54. Carvajal RD, Antonescu CR, Wolchok JD, Chapman PB, Roman RA, Teitcher J, Panageas KS, Busam KJ, Chmielowski B, Lutzky J, et al: KIT as a therapeutic target in metastatic melanoma. JAMA: the journal of the American Medical Association 2011, 305(22):2327-2334.

55. Kluger HM, Dudek AZ, McCann C, Ritacco J, Southard N, Jilaveanu LB, Molinaro A, Sznol M: A phase 2 trial of dasatinib in advanced melanoma. Cancer 2011, 117(10):2202-2208.

56. Riese DJ, Gallo RM, Settleman J: Mutational activation of ErbB family receptor tyrosine kinases: insights into mechanisms of signal transduction and tumorigenesis. Bioessays 2007, 29(6):558-565.

57. Frey MR, Edelblum KL, Mullane MT, Liang D, Polk DB: The ErbB4 growth factor receptor is required for colon epithelial cell survival in the presence of TNF. Gastroenterology 2009, 136(1):217-226.

58. Prickett TD, Agrawal NS, Wei X, Yates KE, Lin JC, Wunderlich JR, Cronin JC, Cruz P, Rosenberg SA, Samuels Y: Analysis of the tyrosine kinome in melanoma reveals recurrent mutations in ERBB4. Nat Genet 2009, 41(10):1127-1132.

59. Graells J, Vinyals A, Figueras A, Llorens A, Moreno A, Marcoval J, Gonzalez FJ, Fabra A: Overproduction of VEGF concomitantly expressed with its receptors promotes growth and survival of melanoma cells through MAPK and PI3K signaling. J Invest Dermatol 2004, 123(6):1151-1161.

60. Srivastava A, Ralhan R, Kaur J: Angiogenesis in cutaneous melanoma: pathogenesis and clinical implications. Microsc Res Tech 2003, 60(2):208-224.

61. Perez DG, Suman VJ, Fitch TR, Amatruda T, Morton RF, Jilani SZ, Constantinou CL, Egner JR, Kottschade LA, Markovic SN: Phase 2 trial of carboplatin, weekly paclitaxel, and biweekly bevacizumab in patients with unresectable stage IV melanoma: a North Central Cancer Treatment Group study, N047A. Cancer 2009, 115(1):119-127.

62. Kim KB, Sosman JA, Fruehauf JP, Linette GP, Markovic SN, McDermott DF, Weber JS, Nguyen $H$, Cheverton $P$, Chen D, et al: BEAM: A Randomized Phase II Study Evaluating the Activity of Bevacizumab in Combination With Carboplatin Plus Paclitaxel in Patients With Previously Untreated Advanced Melanoma. Journal of clinical oncology: official journal of the American Society of Clinical Oncology 2012, 30(1):34-41.

63. Kottschade LA, Suman VJ, Amatruda T, McWilliams RR, Mattar Bl, Nikcevich DA, Behrens R, Fitch TR, Jaslowski AJ, Markovic SN: A phase II trial of nab-paclitaxel (ABI-007) and carboplatin in patients with unresectable stage IV melanoma: a North Central Cancer Treatment Group Study, N057E(1). Cancer 2011, 117(8):1704-1710.

64. Fruehauf JP, Lutzky J, McDermott DF, Brown CK, Meric JB, Rosbrook B, Shalinsky DR, Liau KF, Niethammer AG, Kim S, et al: Multicenter, Phase II Study of Axitinib, a Selective Second-Generation Inhibitor of Vascular Endothelial Growth Factor Receptors 1, 2, 3, in Patients with Metastatic Melanoma. Clinical cancer research: an official journal of the American Association for Cancer Research 2011.

65. Hong DS, Koetz BS, Kurzrock R, Senzer NN, Hanekom W, Naing A, Wheler JJ, Mink J, Ren M, Nemunaitis JJ: Phase I dose-escalation study of E7080, a selective tyrosine kinase inhibitor, administered orally to patients with solid tumors. ASCO Meeting Abstracts 2010, 28(15_suppl):2540. 
66. Keir ME, Butte MJ, Freeman GJ, Sharpe AH: PD-1 and its ligands in tolerance and immunity. Annu Rev Immunol 2008, 26:677-704.

67. Riley JL: PD-1 signaling in primary T cells. Immunol Rev 2009, 229(1):114-125.

68. Okazaki T, Honjo T: The PD-1-PD-L pathway in immunological tolerance. Trends Immunol 2006, 27(4):195-201.

69. Brahmer JR, Drake CG, Wollner I, Powderly JD, Picus J, Sharfman WH, Stankevich E, Pons A, Salay TM, McMiller TL, et al: Phase I study of singleagent anti-programmed death-1 (MDX-1106) in refractory solid tumors: safety, clinical activity, pharmacodynamics, and immunologic correlates. J Clin Oncol 2010, 28(19):3167-3175.

70. Rosenberg SA, Packard BS, Aebersold PM, Solomon D, Topalian SL, Toy ST, Simon P, Lotze MT, Yang JC, Seipp CA, et al: Use of tumor-infiltrating lymphocytes and interleukin-2 in the immunotherapy of patients with metastatic melanoma. A preliminary report. N Engl J Med 1988, 319(25):1676-1680.

71. Rosenberg SA, Yannelli JR, Yang JC, Topalian SL, Schwartzentruber DJ, Weber JS, Parkinson DR, Seipp CA, Einhorn JH, White DE: Treatment of patients with metastatic melanoma with autologous tumor-infiltrating lymphocytes and interleukin 2. J Natl Cancer Inst 1994, 86(15):1159-1166.

72. Rosenberg SA, Dudley ME: Cancer regression in patients with metastatic melanoma after the transfer of autologous antitumor lymphocytes. Proc Natl Acad Sci USA 2004, 101(Suppl 2):14639-14645.

73. Dudley ME, Wunderlich JR, Yang JC, Sherry RM, Topalian SL, Restifo NP, Royal RE, Kammula U, White DE, Mavroukakis SA, et al: Adoptive cell transfer therapy following non-myeloablative but lymphodepleting chemotherapy for the treatment of patients with refractory metastatic melanoma. J Clin Oncol 2005, 23(10):2346-2357.

74. Rosenberg SA, Yang JC, Sherry RM, Kammula US, Hughes MS, Phan GQ, Citrin DE, Restifo NP, Robbins PF, Wunderlich JR, et al: Durable complete responses in heavily pretreated patients with metastatic melanoma using T-cell transfer immunotherapy. Clin Cancer Res 2011, 17(13):4550-4557.

75. Dudley ME: Adoptive cell therapy for patients with melanoma. J Cancer 2011, 2:360-362.

76. Joseph RW, Peddareddigari VR, Liu P, Miller PW, Overwijk WW, Bekele NB, Ross MI, Lee JE, Gershenwald JE, Lucci A, et al: Impact of clinical and pathologic features on tumor-infiltrating lymphocyte expansion from surgically excised melanoma metastases for adoptive T-cell therapy. Clin Cancer Res 2011, 17(14):4882-4891.

77. Morgan RA, Dudley ME, Wunderlich JR, Hughes MS, Yang JC, Sherry RM, Royal RE, Topalian SL, Kammula US, Restifo NP, et al: Cancer regression in patients after transfer of genetically engineered lymphocytes. Science 2006, 314(5796):126-129.

78. Joseph RW, Sullivan RJ, Harrell R, Stemke-Hale K, Panka D, Manoukian G, Percy A, Bassett RL, Ng CS, Radvanyi L, et al: Correlation of NRAS mutations with clinical response to high-dose IL-2 in patients with advanced melanoma. Journal of Immunotherapy 2012, 35(1):66-72.

79. Sabatino M, Kim-Schulze S, Panelli MC, Stroncek D, Wang E, Taback B, Kim DW, Deraffele G, Pos Z, Marincola FM, et al: Serum vascular endothelial growth factor and fibronectin predict clinical response to high-dose interleukin-2 therapy. J Clin Oncol 2009, 27(16):2645-2652.

80. Schwartzentruber DJ, Lawson DH, Richards JM, Conry RM, Miller DM, Treisman J, Gailani F, Riley L, Conlon K, Pockaj B, et al: gp100 peptide vaccine and interleukin-2 in patients with advanced melanoma. $N$ Engl J Med 2011, 364(22):2119-2127.

81. Joseph RW, Hwu P, Davies MA, Atkins MB, Sullivan RJ: Clinical benefit of ipilimumab in patients with metastatic melanoma who progress on high-dose IL-2. ASCO Meeting Abstracts 2011, 29(15_suppl):8537.

82. Boni A, Cogdill AP, Dang P, Udayakumar D, Njauw CN, Sloss CM, Ferrone $C R$, Flaherty $K T$, Lawrence DP, Fisher DE, et al: Selective BRAFV600E inhibition enhances T-cell recognition of melanoma without affecting lymphocyte function. Cancer research 2010, 70(13):5213-5219.

83. Allen PJ, Coit DG: The surgical management of metastatic melanoma. Ann Surg Oncol 2002, 9(8):762-770.

84. Meyer T, Merkel S, Goehl J, Hohenberger W: Surgical therapy for distant metastases of malignant melanoma. Cancer 2000, 89(9):1983-1991.

85. Leo F, Cagini L, Rocmans P, Cappello M, Geel AN, Maggi G, Goldstraw P, Pastorino U: Lung metastases from melanoma: when is surgical treatment warranted? Br J Cancer 2000, 83(5):569-572.
86. Herman P, Machado MA, Montagnini AL, D'Albuquerque LA, Saad WA, Machado MC: Selected patients with metastatic melanoma may benefit from liver resection. World J Surg 2007, 31(1):171-174.

87. Rose DM, Essner R, Hughes TM, Tang PC, Bilchik A, Wanek LA, Thompson JF, Morton DL: Surgical resection for metastatic melanoma to the liver: the John Wayne Cancer Institute and Sydney Melanoma Unit experience. Arch Surg 2001, 136(8):950-955.

88. Sosman JA, Moon J, Tuthill RJ, Warneke JA, Vetto JT, Redman BG, Liu PY, Unger JM, Flaherty LE, Sondak VK: A phase 2 trial of complete resection for stage IV melanoma: Results of Southwest Oncology Group Clinical Trial S9430. Cancer 2011.

\section{Pre-publication history}

The pre-publication history for this paper can be accessed here: http://www.biomedcentral.com/1741-7015/10/23/prepub

doi:10.1186/1741-7015-10-23

Cite this article as: Finn et al:: Therapy for metastatic melanoma: the past, present, and future. BMC Medicine 2012 10:23.

\section{Submit your next manuscript to BioMed Central and take full advantage of:}

- Convenient online submission

- Thorough peer review

- No space constraints or color figure charges

- Immediate publication on acceptance

- Inclusion in PubMed, CAS, Scopus and Google Scholar

- Research which is freely available for redistribution

Submit your manuscript at www.biomedcentral.com/submit
Biomed Central 